\title{
First report of bacterial endophytes from the leaves of Pellaea calomelanos in South Africa
}

Siphiwe G. Mahlangu ${ }^{1}$

Mahloro H. Serepa-Dlamini'

\section{AFFILIATION:}

'Department of Biotechnology and Food Technology, University of Johannesburg, Johannesburg, South Africa

\section{CORRESPONDENCE TO:}

Mahloro Serepa-Dlamini

\section{EMAIL:}

hopes@uj.ac.za

\section{DATES:}

Received: 16 0ct. 2017

Revised: 18 Jan. 2018

Accepted: 21 May 2018

Published: 11 Sep. 2018

\section{KEYWORDS:}

Pantoea; medicinal plant; phylogenetic analysis; biolog micro-station; 16S rRNA gene

\section{HOW TO CITE:}

Mahlangu SG, Serepa-Dlamini $\mathrm{MH}$. First report of bacterial endophytes from the leaves of Pellaea calomelanos in South Africa. S Afr J Sci. 2018;114(9/10), Art. \#4235, 9 pages. https://doi. org/10.17159/sajs.2018/4235

\section{ARTICLE INCLUDES:}

$\times$ Supplementary material

$\times$ Data set

FUNDING:

University of Johannesburg
(C) 2018. The Author(s). Published under a Creative Commons Attribution Licence.
Bacteria have an endosymbiotic association with plants. Previous studies have identified endophytic bacteria and their importance in biocontrol and drug development. However, most medicinal plants identified have not been assayed for bacterial endophytes. In this study, we characterised and identified bacterial endophytes from surface-sterilised leaves of Pellaea calomelanos, a common fern in the Limpopo and Gauteng Provinces, South Africa. Using morphological data and 16S rRNA gene sequencing, we differentiated and identified six putative endophytic bacteria, with Pantoea as the dominant genus; the other two identified bacteria belong to genera Arthrobacter and Bacillus. Data from this study are an addition to the previously less studied phylloplane bacteria. This study is a pilot in cataloguing bacterial endophytes from Pellaea calomelanos.

Significance:

- This study provides the first report of six putative bacterial endophytes from Pellaea calomelanos.

- $\quad$ Our results will pave the way for exploring the antimicrobial activity of $P$. calomelanos bacterial endophytes and whole genome comparisons between plant bacterial endophytes and plant bacterial pathogens.

\section{Introduction}

Plants have a mutualistic relationship with varied endophytes. ${ }^{1}$ Endophytes are endosymbiotic; they are often bacterial or fungal species which colonise the plants without causing harm or pathogenic infection ${ }^{3}$ and can spend part or their entire life cycle within the plant host ${ }^{2-4}$.

Most plant species are known to host one or more endophytic microorganisms. ${ }^{5}$ Endophytes form a symbiotic relationship with the plants by providing a biological defence mechanism for the plant host against pathogens, ${ }^{2-5}$ through the production of secondary metabolites. These metabolites halt the growth of or attack invading antagonists or lyse-infected plant cells; furthermore, the metabolites can induce plant host defence mechanisms and promote plant growth. ${ }^{6}$

The present study was designed to isolate, identify and characterise endophytic bacteria from Pellaea calomelanos obtained in South Africa. Pteridaceae is a family of fern plants with over 45 genera and more than 1000 species. ${ }^{7}$ One such genus is Pellaea with over 35 described species found growing in arid rocky regions and within narrow open pockets in the soil. 7,8 P. calomelanos is a common fern species in the Limpopo and Gauteng Provinces of South Africa, but also grows throughout the rest of the country. ${ }^{9}$ Common names of $P$. calomelanos in South Africa include inkomankomo (Zulu), lehorometso (Sotho), legogoana (Tswana), phalatjane (Sepedi) and hard fern (English). ${ }^{9}$

$P$. calomelanos is a multipurpose medicinal plant used for the treatment of headaches, chest colds, asthma, head colds and mouth and nasal ulcers. ${ }^{9}$ Like other plants, Pellaea species have a mutualistic relationship with endophytes, although, to date, endophytes have been reported in only $P$. concolor and $P$. viridis. ${ }^{10,11}$ We thus report here on the occurrence of bacterial endophytes within the leaves of $P$. calomelanos. Ours is the first study to describe the isolation, identification and characterisation of bacterial endophytes from $P$. calomelanos using morphological and phenotypic characteristics and the sequencing of the 16S rRNA gene.

\section{Materials and methods}

\section{Collection of plant material}

Aerial portions of the plant material were collected from Botlokwa (23⒉'34.8'S, $\left.29^{\circ} 42^{\prime} 11.2^{\prime} \mathrm{E}\right)$ in the Limpopo Province of South Africa. Whole plants were placed in sterile polyethylene bags and transported to the laboratory under $4{ }^{\circ} \mathrm{C}$. The plant material was collected in March 2017 from a site with sandy loam soil.

\section{Identification of the plant material}

The identification of the plant material was carried out at the University of Johannesburg Herbarium (JRAU). A sample specimen of the plant material was deposited in the University of Johannesburg Herbarium (JRAU) with voucher specimen number Serepa-Dlamini 201 and species name Pellaea calomelanos. The remaining collected plant material was immediately processed in the laboratory.

\section{Isolation of endophytic bacteria}

Immediately after collection of plant material in the lab, plant leaves were washed with running tap water followed by a sequential sterilisation with the following solutions: sterile distilled water for $1 \mathrm{~min}, 70 \%$ ethanol for $1.5 \mathrm{~min}, 1 \%$ sodium hypochlorite for $3 \mathrm{~min}$ and finally washed three times in sterile distilled water. The final washing water was then plated as control. The surface-sterilised leaves were ground in $2 \mathrm{~mL}$ of saline using a pestle and mortar. Under sterile conditions, the homogenate was streaked onto nutrient agar plates. The plates were incubated for $24-48 \mathrm{~h}$ at $28{ }^{\circ} \mathrm{C}$ and inspected daily for bacterial colony growth. Isolated colonies were re-cultured on sterile nutrient agar plates until pure colonies with uniform morphology were obtained. For each endophyte bacterial isolate, $35 \%$ glycerol (glycerol diluted in sterile distilled water) stock cultures were prepared and stored at $-80^{\circ} \mathrm{C}$ for future use. 


\section{Preliminary identification of endophytic bacterial isolates}

Pure colonies were subjected to a Gram reaction test. ${ }^{12}$ The SchaefferFulton stain method ${ }^{13}$ was conducted to determine if the bacterial endophytes produced endospores. The hanging-drop method adapted from MacFaddin ${ }^{14}$ was used to determine motility of the bacterial isolates. All the prepared slides were examined using a bright-field compound light microscope (CX21FS1, Olympus Corporation, Tokyo, Japan) with 400x and $1000 x$ magnification.

\section{Identification of bacterial endophytes by the Biolog MicroPlate system}

The following procedure was utilised to identify the putative endophyte bacterial isolates. Under sterile conditions, overnight single colonies of the isolates were sub-cultured in six separate $5 \mathrm{~mL}$ of $0.85 \%$ saline solution. The Biolog turbidimeter was used to monitor and measure the turbidity of the suspension until a $90-98 \%$ transmittance was reached. The suspension $(150 \mu \mathrm{L})$ was aliquoted into each well of the Biolog MicroPlate (with GEN III MicroPlate ${ }^{\mathrm{TM}}$; Biolog Inc., Hayward, CA, USA) and incubated at $26^{\circ} \mathrm{C}$ for $24 \mathrm{~h}$. The plates were scanned using the Biolog automatic system and samples identified using the Biolog software. ${ }^{15}$

\section{Scanning electron microscopy}

A scanning electron microscope was used to observe and study the shape of the endophyte bacterial isolates. Each glycerol stock of the isolated bacterial endophytes was inoculated into $5 \mathrm{~mL}$ nutrient broth and incubated for $48 \mathrm{~h}$ at $28{ }^{\circ} \mathrm{C}$. The bacterial suspension was centrifuged at $2935 \mathrm{rcf}$ for $10 \mathrm{~min}$, the supernatant was discarded and bacterial cells were rinsed with sterile distilled water three times with a 5-min interval between each rinse. The bacterial cells were then fixed in $8 \%$ glutaraldehyde overnight (glutaraldehyde $25 \%$ EM grade diluted in Ringers' solution). Sterile distilled water was used to rinse the cells twice, followed by a series of dehydration with $30 \%, 50 \%, 70 \%, 90 \%, 95 \%$ and $100 \%$ ethanol at 10 -min intervals and a centrifugation step at $2935 \mathrm{rcf}$ for $10 \mathrm{~min}$. The bacterial pellets were left to dry overnight in open Eppendorf tubes placed in a refrigerator at $4^{\circ} \mathrm{C}$. The cells were then mounted on scanning electron microscope stubs and coated with gold and viewed using the TESCAN VEGA 3 LMH (AVG9731276ZA, Warrendale, PA, USA) scanning electron microscope fitted with a digital camera.

\section{Identification of bacterial endophytes using 16 S rRNA}

\section{Extraction of genomic DNA}

Genomic DNA of each bacterial isolate was extracted from nutrient agar pure colonies using a Quick-DNATM ZR fungal/bacterial DNA MiniPrep kit (Zymo Research, Irvine, CA, USA) according to the manufacturer's protocol. The extracted DNA was quantified using the NanoDrop ND2000 UV-Vis spectrophotometer (ThermoFisher Scientific, USA); the DNA concentration was $40 \mathrm{ng} / \mu \mathrm{L}$ prior to cleaning with ZR fungal/ bacterial DNA clean and concentrator-5 (Zymo Research).

\section{Polymerase chain reaction amplification and sequencing}

The 16S rRNA gene of each bacterial isolate was amplified by polymerase chain reaction (PCR) in a $12.5-\mu \mathrm{L}$ reaction containing $1.5 \mu \mathrm{L}$ of template DNA, $1.5 \mu \mathrm{L}$ of each primer $5{ }^{\text {-AGAGTTTGATCCTGGCTCAG-3 }}{ }^{\prime} \mathrm{f}$ and $5{ }^{`}$-AAGGAGGTGATCCAAGCCGCA-3 ${ }^{`} \mathrm{r}, 6 \mu \mathrm{L}$ of One Taq ${ }^{\circledR}$ 2X PCR master mix with standard buffer $\left(20 \mathrm{mM}\right.$ Tris- $\mathrm{HCl}, 1.8 \mathrm{mM} \mathrm{MgCl}, 22 \mathrm{mM} \mathrm{NH}_{4} \mathrm{Cl}$, $22 \mathrm{mM} \mathrm{KCl}, 0.2 \mathrm{mM}$ dNTPs, 5\% glycerol, 0.06\% IGEPAL ${ }^{\circledR}$ CA-630, 0.05\% Tween $^{\circledR} 20,25$ units/mL One Taq ${ }^{\circledR}$ DNA polymerase) and final volume filled up to $12.5 \mu \mathrm{L}$ with nuclease free water. The PCR cycle was performed using MyCycler ${ }^{\mathrm{TM}}$ Thermal Cycler (catalogue number 580BR 08389, BioRad, Hercules, CA, USA) with the following conditions: initial denaturation at $94{ }^{\circ} \mathrm{C}$ for $3 \mathrm{~min}$, followed by 35 cycles of amplification: denaturation at $94^{\circ} \mathrm{C}$ for $1 \mathrm{~min}, 55^{\circ} \mathrm{C}$ for $1 \mathrm{~min}$ (annealing), $72^{\circ} \mathrm{C}$ for 2 min (extension), followed by a final extension at $72{ }^{\circ} \mathrm{C}$ for 10 min. ${ }^{16}$ The PCR products were cleaned with ExoSAP-it ${ }^{\mathrm{TM}}$ (ThermoFisher Scientific) following the manufacturer's recommendations and sent for sequencing with primers to Inqaba Biotechnical Industries (Pty) Ltd, Pretoria, South Africa.

\section{Phylogenetic analysis}

The 16S rRNA gene sequences of the bacterial isolates were subjected to BLAST (v.2.6.0) analysis against the rRNA sequence database (Bacteria and Archaea) at the National Center for Biotechnology Information (NCBI) to identify the closest related bacterial species. Only bacterial species with $95-100 \%$ identity similarity were selected for phylogenetic analysis. The aligned sequences, containing the isolate and closest related bacterial species, were determined by MUSCLE ${ }^{17}$ and phylogenetic analysis carried out using the maximum likelihood method based on the TamuraNei model ${ }^{17}$. Positions overlapping with gaps and missing nucleotide data were eliminated. All evolutionary analyses were conducted in MEGA $7 .^{18}$ Escherichia coli ATCC 11775T with GenBank accession number X80725 was used as the outgroup. The phylogenetic trees were reported with bootstrap percentages. The $16 \mathrm{~S}$ rRNA gene sequences of bacterial isolates identified in the study were deposited in GenBank (https:// www.ncbi.nlm.nih.gov/genbank) with the following accession numbers and names: MF613647 (Arthrobacter sp. strain MHSD1), MF613648 (Pantoea sp. strain MHSD2), MF613649 (Bacillus infantis strain MHSD3), MF613650 (Pantoea sp. strain MHSD4), MF613651 (Pantoea ananatis strain MHSD5) and MF613652 (Pantoea sp. strain MHSD6). The assigned names of the bacterial isolates were based on the BLAST homology percentages as well as phylogenetic results.

\section{Results and discussion}

\section{Isolation and identification of endophytic bacteria}

\section{Morphological identification}

The isolation and enumeration of endophytes from surface-sterilised plant material is the recommended method. ${ }^{3,4,19-23}$ In the current study, six different putative bacterial endophytes were isolated from the surfacesterilised leaves of $P$. calomelanos obtained from Botlokwa, Limpopo Province, South Africa. Previous studies on bacterial endophytes have focused on rhizosphere bacterial endophytes because of their major role in nutrient uptake and high diversity in soils. ${ }^{19-21}$

Preliminary morphological observations of the six isolated colonies that included the production of endospores, motility and Gram staining has enabled the grouping of the bacterial cultures into various groups, some with similar characteristics as shown in Table 1. The Gram stain results indicated that all bacteria were rod shaped and two out of the six isolates were Gram positive and the remaining four isolates were Gram negative. Only one of the Gram-positive isolates was an endospore former. All the isolates, except one Gram-positive isolate, exhibited motility. The morphological shapes were confirmed by the scanning electron microscope results (not shown) which showed uniform cells depicting pure cultures of the bacterial isolates.

\section{Biolog MicroPlates}

The phenotypic assays were performed on the isolates using the Biolog MicroPlates (GEN III MicroPlate) and the results are presented in Table 1. The bacterial isolates can be differentiated based on the utilisation of some of the carbon sources such as dextrin, maltose, sucrose, stachyose and pectin. Most of the isolates appear to hydrolyse these carbon sources, although variations were observed. Some of the results were not determined (ND), such as utilisation of $\mathrm{N}$-acetyl-d-glucosamine, $\mathrm{N}$-acetyl$\beta$-d-mannosamine and $\mathrm{N}$-acetyl neuraminic acid, and thus we cannot rely solely on the phenotypic tests for variation of the bacterial isolates.

The Biolog system can identify bacterial species both at genus and species levels, as well as through Gram stain reaction. The system does so by providing four top-ranked species for identification; Table 2 indicates that isolates 2, 4, 5 and 6 were Gram negative and belonged to the Enterobacteriaceae family. Although the species ID levels for these isolates had different species names for each (of the four top-ranked ID species), they all were identified to be of the genus Pantoea. The Gram reaction results obtained here correlate with those performed initially in the study. Isolates 1 and 3 were also predicted to be Gram positive; however, the family names as well as the genus and species names differed among each of the four predicted species names. This difference could be because we utilised a different growth medium from the one recommended in the MicroStation ${ }^{\mathrm{TM}}$ System/MicroLog User Guide. ${ }^{15}$ 
Table 1: $\quad$ Summary of phenotypic characteristics of bacterial endophytes isolated from Pellaea calomelanos

\begin{tabular}{|c|c|c|c|c|c|c|}
\hline Characteristic & 1 & 2 & 3 & 4 & 5 & 6 \\
\hline Gram reaction & + & - & + & - & - & - \\
\hline Colony morphology & White circular & Yellow circular & Pink circular & Yellow circular & Yellow circular & Yellow circular \\
\hline Endospore stain & - & - & + & - & - & - \\
\hline Motility & - & + & + & + & + & + \\
\hline Dextrin & + & + & + & + & + & + \\
\hline Maltose & + & + & - & + & + & + \\
\hline Sucrose & + & + & - & + & + & + \\
\hline Stachyose & - & - & - & - & - & - \\
\hline Ph 6 & + & + & + & + & + & + \\
\hline Ph 5 & + & + & - & ND & ND & ND \\
\hline D-melibiose & - & - & + & ND & ND & ND \\
\hline D-salicin & + & + & - & ND & ND & ND \\
\hline $\mathrm{N}$-acetyl-d-glucosamine & ND & ND & - & + & + & + \\
\hline $\mathrm{N}$-acetyl- $\beta$-d-mannosamine & + & + & - & ND & ND & ND \\
\hline $\mathrm{N}$-acetyl-d-galactosamine & ND & ND & - & ND & ND & ND \\
\hline $\mathrm{N}$-acetyl neuramic acid & - & - & - & ND & ND & ND \\
\hline $1 \% \mathrm{NaCl}$ & + & + & + & + & + & + \\
\hline $4 \% \mathrm{NaCl}$ & + & + & + & + & + & + \\
\hline $8 \% \mathrm{NaCl}$ & - & - & + & - & - & - \\
\hline D-mannose & + & + & ND & + & + & + \\
\hline D-fructose & + & + & + & + & + & + \\
\hline D-galactose & + & + & ND & + & + & + \\
\hline L-rhamnose & + & + & + & + & + & + \\
\hline Inosine & + & + & - & + & + & + \\
\hline \% Sodium lactate & + & + & + & + & + & + \\
\hline Glycerol & + & + & - & + & + & + \\
\hline Pectin & + & + & + & + & + & + \\
\hline Tween 40 & - & - & - & - & - & - \\
\hline
\end{tabular}

Species: 1, Arthrobacter sp. MHSD1; 2, Pantoea sp. MHSD2; 3, Bacillus infantis strain MHSD3; 4, Pantoea infantis strain MHSD4; 5, Pantoea sp. MHSD5; 6, Pantoea sp. MHSD6. + , positive; - negative; ND, not determined

The MicroStation ${ }^{\text {TM }}$ System/MicroLog User Guide ${ }^{15}$ states that if the top four identified species belong to the same or closely related genera, then the identification can be concluded as a positive result. The other parameters that can be considered from the identified results are: the probability (PROB), similarity (SIM) and distance (DIST). These parameters indicate the approximate degree of matching between the MicroPlate results and the corresponding database. SIM $\geq 0.5$, DIST $\leq 5.0$ and PROB close to 1 indicate reliability of the test results. Although the SIM and DIST results of the top ranked ID species for each isolate were greater than 0.5 and less than 5.0 , respectively, the PROB for all isolates was at 0.7 or above 0.7 , which is relatively close to 1 , thus indicating reliable results.
Although the variation of phenotypic tests could not be concluded from the Biolog MicroPlates (GEN III MicroPlate), the system has shown to be reliable when identifying bacterial species to genus level; further identification can be supported by Gram stain reaction and colony morphology. We do, however, recommend that the use of Biolog MicroPlates (GEN III MicroPlate) be complemented with other strain identification methods, despite the current study showing the reliability of identifying bacterial species by use of the Biolog MicroPlates (GEN III MicroPlate). Furthermore, previous studies have identified and examined phenotypic characteristics of bacterial species utilising this system. ${ }^{24-27}$ 
Table 2: Biolog MicroPlate readings of isolated endophytic bacteria

\begin{tabular}{|c|c|c|c|c|c|}
\hline Bacterial isolate number & Species ID & PROB & SIM & DIST & Organism type \\
\hline \multirow{4}{*}{1} & Arthrobacter globiformis & 0.771 & 0.612 & 7.145 & GP-Rod \\
\hline & Arthrobacter oxydans & 0.056 & 0.093 & 8.908 & GP-Rod \\
\hline & Arthrobacter ilicis & 0.034 & 0.047 & 8.04 & GP-Rod \\
\hline & Arthrobacter cummunsii & 0.052 & 0.037 & 8.23 & GP-Rod \\
\hline \multirow{4}{*}{2} & Pantoea agglomerans & 0.814 & 0.520 & 5.216 & GN-Ent \\
\hline & Pantoea dispersa & 0.104 & 0.058 & 6.537 & GN-Ent \\
\hline & Pantoea cypripedii & 0.067 & 0.036 & 6.815 & GN-Ent \\
\hline & Pantoea eucrina & 0.015 & 0.007 & 7.798 & GN-Ent \\
\hline \multirow{4}{*}{3} & Bacillus cereus/thuringiensis & 0.562 & 0.562 & 6.418 & GP-Rod \\
\hline & Brevibacterium linens & 0.160 & 0.160 & 6.720 & GP-Rod \\
\hline & Corynebacterium xerosis & 0.104 & 0.104 & 7.257 & GP-Rod \\
\hline & Micrococcus luteus D & 0.072 & 0.072 & 7.721 & GP-Coccus \\
\hline \multirow{4}{*}{4} & Pantoea agglomerans & 0.610 & 0.610 & 5.622 & GN-Ent \\
\hline & Pantoea dispersa & 0.089 & 0.089 & 6.596 & GN-Ent \\
\hline & Pantoea cypripedii & 0.053 & 0.053 & 6.907 & GN-Ent \\
\hline & Pantoea eucrina & 0.007 & 0.007 & 8.155 & GN-Ent \\
\hline \multirow{4}{*}{5} & Pantoea agglomerans & 0.575 & 0.575 & 6.260 & GN-Ent \\
\hline & Pantoea dispersa & 0.102 & 0.102 & 7.504 & GN-Ent \\
\hline & Pantoea cypripedii & 0.101 & 0.101 & 7.526 & GN-Ent \\
\hline & Pantoea eucrina & 0.047 & 0.047 & 8.486 & GN-Ent \\
\hline \multirow{4}{*}{6} & Pantoea agglomerans & 0.603 & 0.603 & 5.744 & GN-Ent \\
\hline & Pantoea dispersa & 0.104 & 0.104 & 7.118 & GN-Ent \\
\hline & Pantoea cypripedii & 0.086 & 0.086 & 7.343 & GN-Ent \\
\hline & Pantoea eucrina & 0.057 & 0.057 & 7.862 & GN-Ent \\
\hline
\end{tabular}

PROB, probability; SIM, similarity; DIS, distance between \#1 and \#2 species

GN, Gram negative; GP, Gram positive. The name appearing after the Gram stain result refers to either family or shape of identified bacteria; Ent, Enterobacteriaceae; Rod, rod shaped; Coccus, spherical or ovoid shaped.

\section{Phylogenetic analysis}

The 16S rRNA gene sequence lengths (in base pairs) are shown in Table 3. The NCBI BLAST search results indicated that bacterial endophyte isolate number 1 had a 100\% identity similarity with Arthrobacter spp., bacterial endophyte isolate 3 had 100\% identity similarity with Bacillus spp. and bacterial endophyte isolates 2, 4, 5 and 6 had $99 \%$ identity similarities with Pantoea spp. These results indicate that the dominating endophytic bacteria from Pellaea calomelanos belong to the genus Pantoea. The homology percentage identity was performed among all the bacterial isolates (results not shown). The lowest homology similarity percentage was observed between Arthrobacter vs Bacillus, Arthrobacter vs Pantoea and Bacillus vs Pantoea isolates, indicating that these are different species. There was, however, a $99 \%$ homology similarity between all the Pantoea isolates. These isolates were further resolved with phylogenetic analysis (Figures 1-6).

All the delineated phylogenetic trees for the isolates had polytomy relations with closely related species. Isolate 1 had a polytomy relationship with undescribed Arthrobacter species and Arthrobacter polychromogenes (Figure 1) with a $47 \%$ bootstrap value. Isolate 3 had a polytomy relationship supported by a $98 \%$ bootstrap value with undescribed Bacillus species and other strains of Bacillus infantis (Figure 3). Isolates 2, 4, 5 and 6 had polytomy relationships with closely related Pantoea species and all showed varying bootstrap values - the phylogenetic relationships were different for each isolate indicating that these are different Pantoea species (Figures 2, 4, 5 and 6). A delineated tree including all the isolated Pantoea species showed that Pantoea sp. MHSD2 and Pantoea sp. MHSD4 had a monophyletic relation supported by a $60 \%$ bootstrap value, whereas Pantoea sp. MHSD5 and Pantoea sp. MHSD6 had a polytomy relationship with Pantoea eucalypti and P. brenneri species (Figure 7). The 16S rRNA gene sequence is the foremost molecular marker used to identify bacterial species; however, from the results obtained, it is evident that 16S rRNA does not resolve the phylogenetic and evolutionary relationships between closely related bacterial strains. The phylogeny of these closely related bacterial strains can be resolved with the use of multilocus sequence analysis. ${ }^{28}$ 


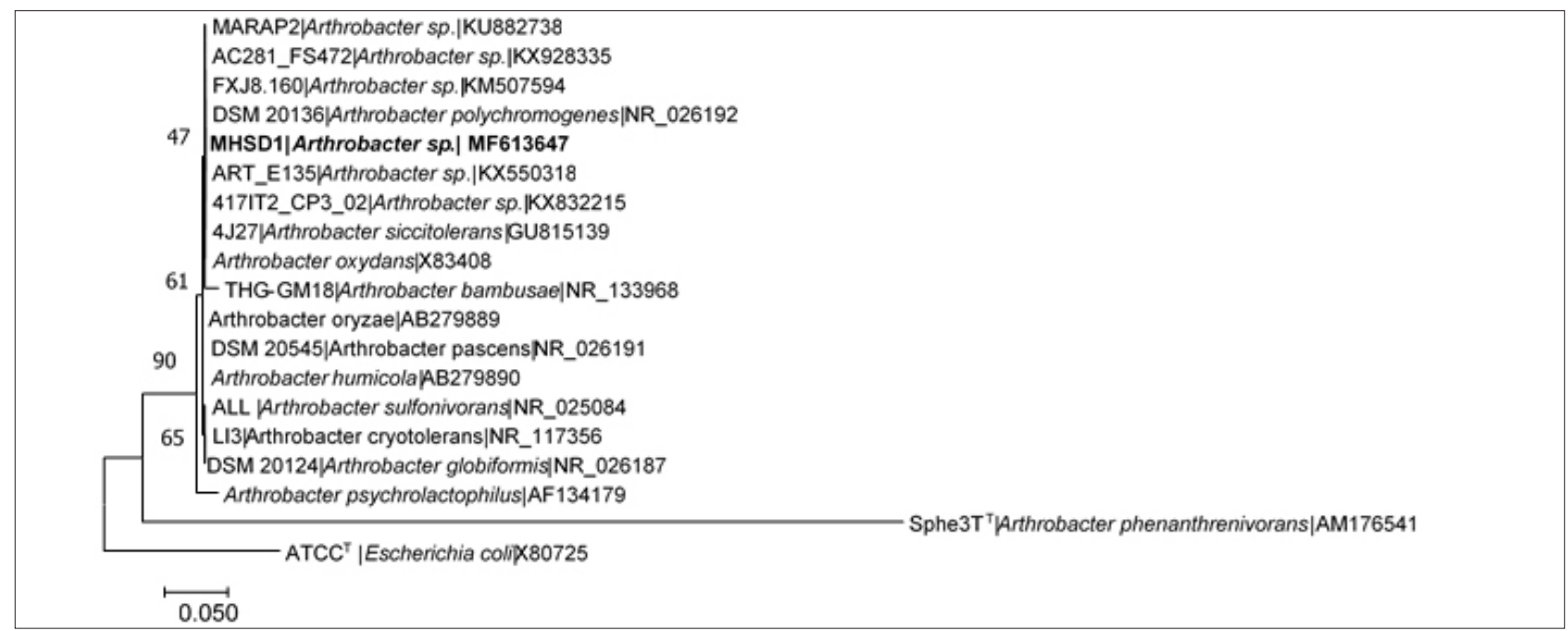

Figure 1: Maximum likelihood tree based on the 16S rRNA gene sequences of Arthrobacter sp. MHSD1 and its closest phylogenetic neighbours. The numbers on nodes indicate bootstrap values after 1000 replicates expressed in percentages. Escherichia coli strain ATCC X80725 was included as an outgroup. ${ }^{\top}$ indicates type strains.

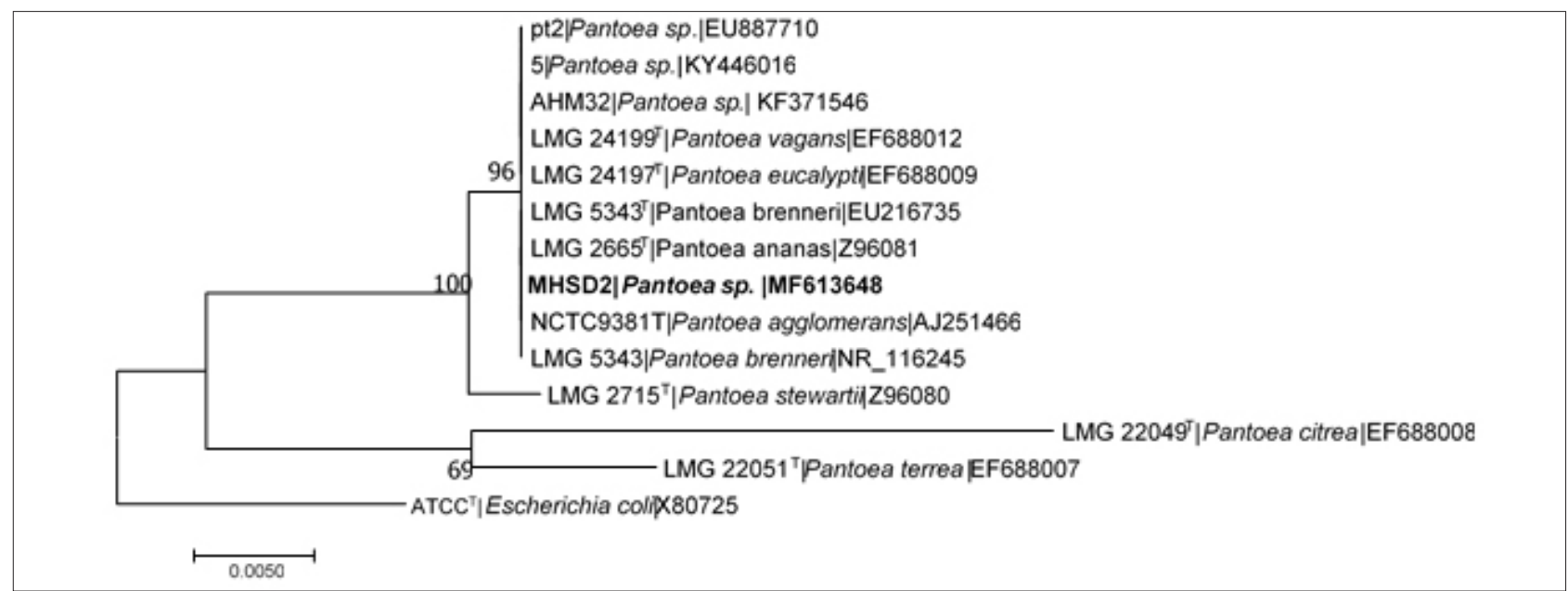

Figure 2: Maximum likelihood tree based on the 16S rRNA gene sequences of Pantoea sp. MHSD2 and its closest phylogenetic neighbours. The numbers on nodes indicate bootstrap values after 1000 replicates expressed in percentages. Escherichia coli strain ATCC X80725 was included as an outgroup. ${ }^{\top}$ indicates type strains.

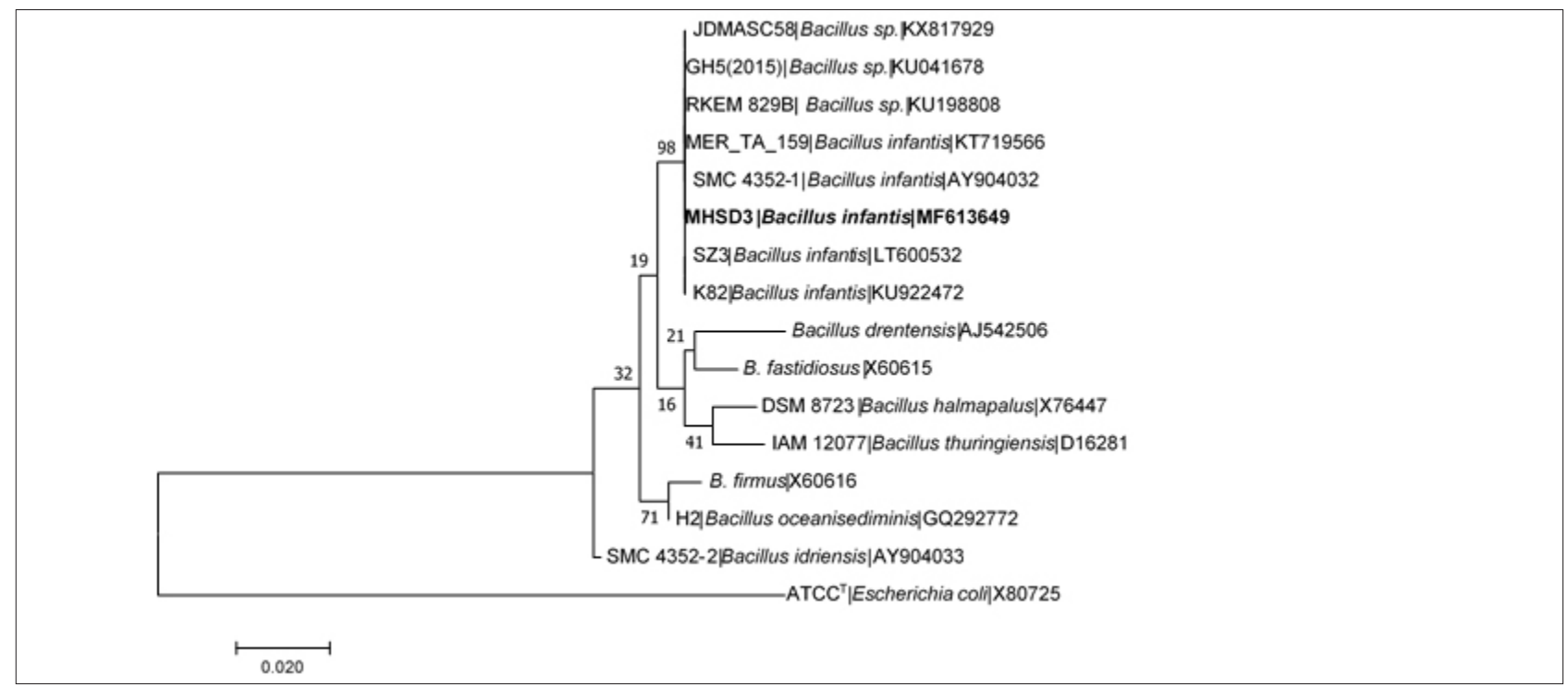

Figure 3: Maximum likelihood tree based on the 16S rRNA gene sequences of Bacillus infantis strain MHSD3 and its closest phylogenetic neighbours. The numbers on nodes indicate bootstrap values after 1000 replicates expressed in percentages. Escherichia coli strain ATCC X80725 was included as an outgroup. ${ }^{\top}$ indicates type strains. 


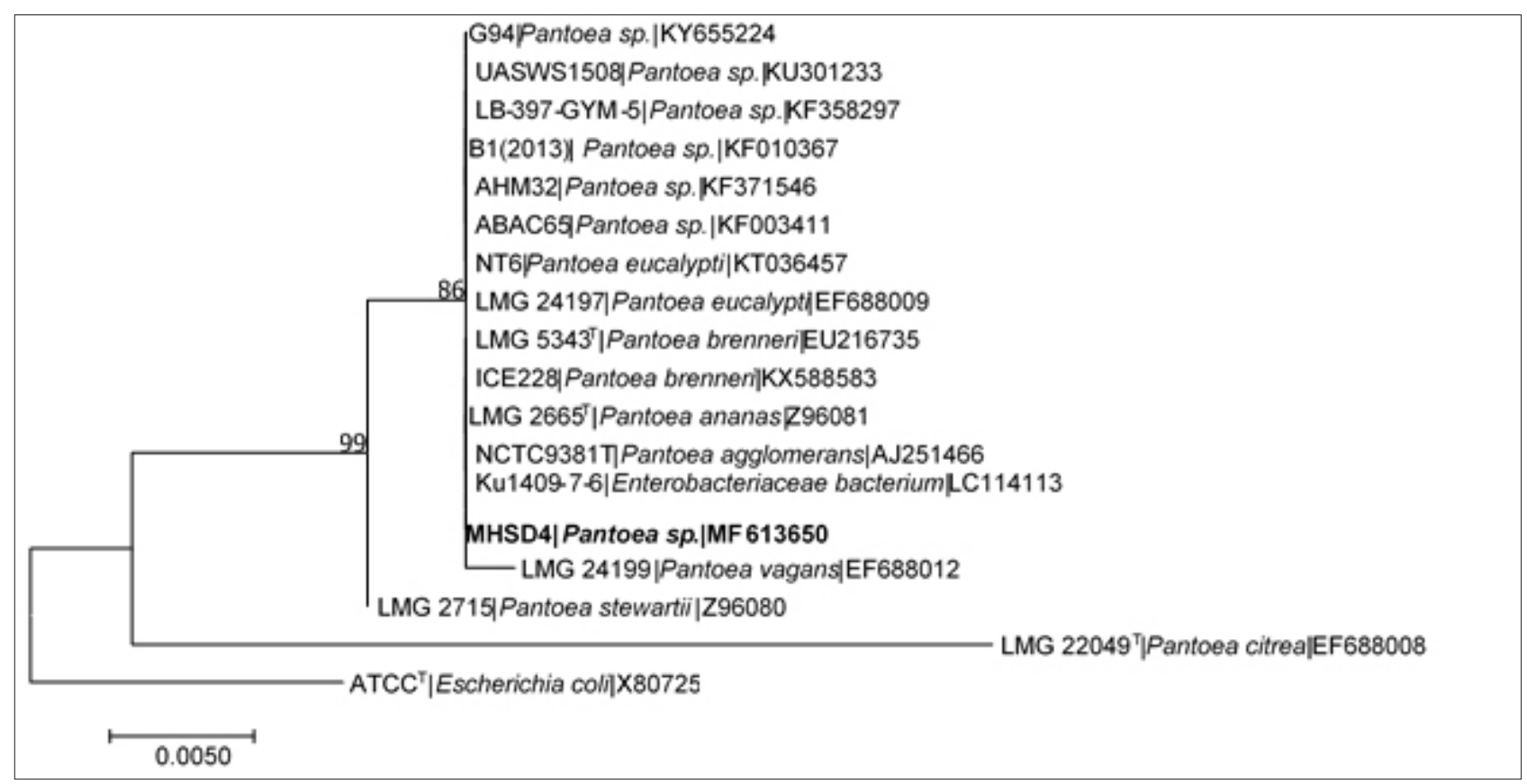

Figure 4: Maximum likelihood tree based on the 16S rRNA gene sequences of Pantoea sp. strain MHSD4 and its closest phylogenetic neighbours. The numbers on nodes indicate bootstrap values after 1000 replicates expressed in percentages. Escherichia coli strain ATCC X80725 was included as an outgroup. 'indicates type strains.

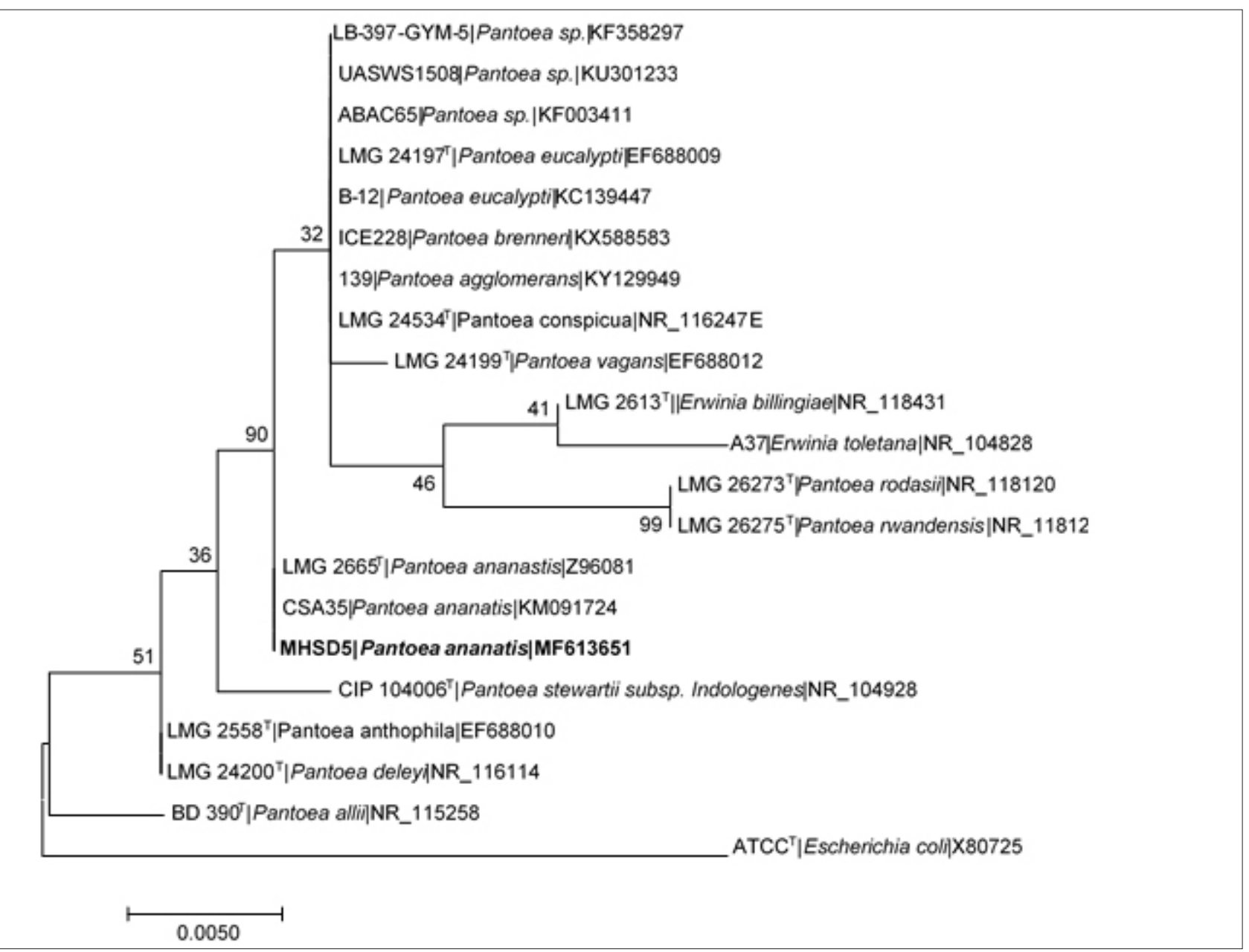

Figure 5: Maximum likelihood tree based on the 16S rRNA gene sequences of Pantoea ananatis strain MHSD5 and its closest phylogenetic neighbours. The numbers on nodes indicate bootstrap values after 1000 replicates expressed in percentages. Escherichia coli strain ATCC X80725 was included as an outgroup. 'ंindicates type strains. 


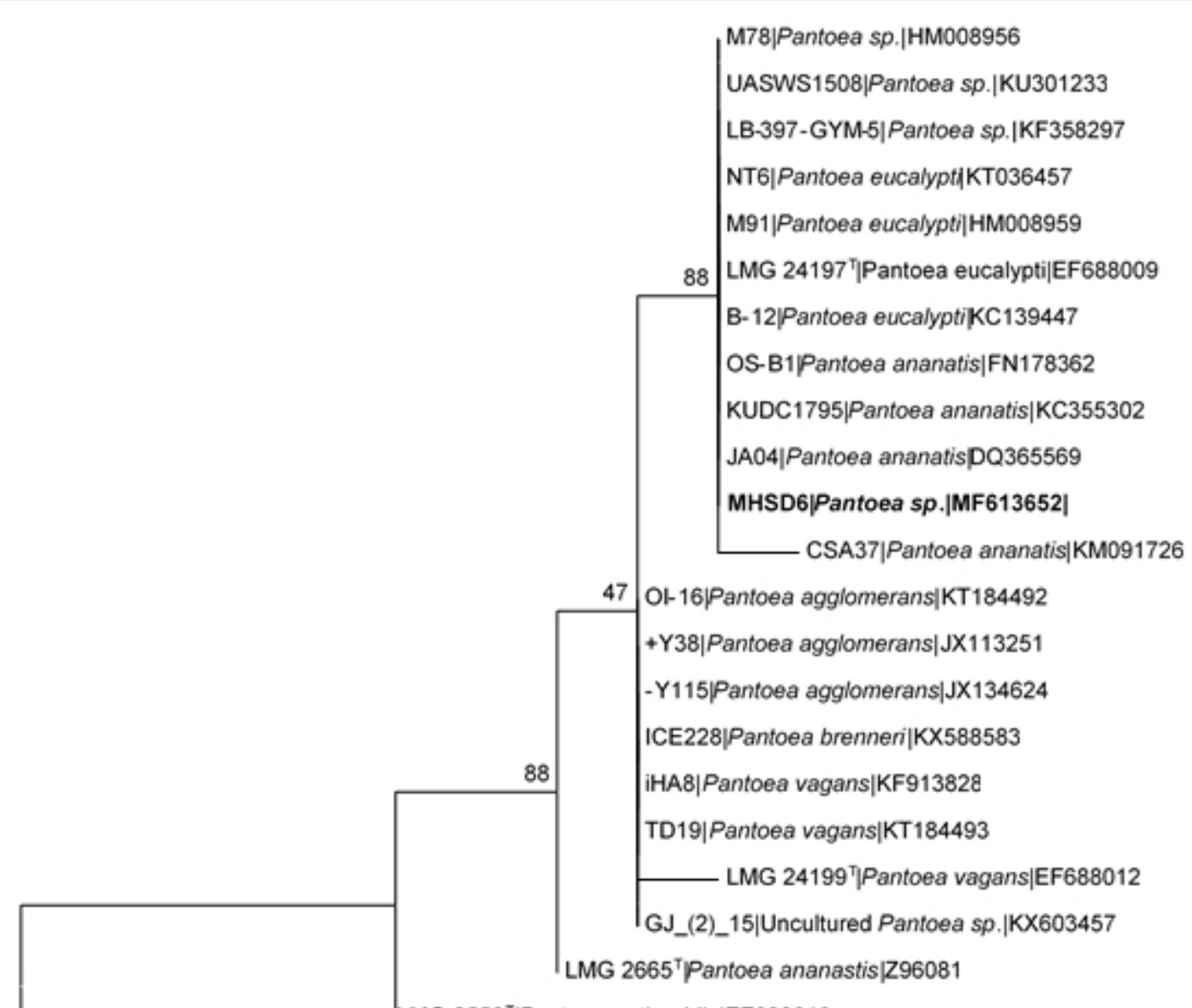

LMG $2558^{\top}$ Pantoea anthophila|EF688010

ATCC|Escherichia coli |X80725

0.0050

Figure 6: Maximum likelihood tree based on the 16S rRNA gene sequences of Pantoea sp. MHSD6 and its closest phylogenetic neighbours. The numbers on nodes indicate bootstrap values after 1000 replicates expressed in percentages. Escherichia coli strain ATCC X80725 was included as an outgroup. ' ${ }^{\top}$ indicates type strains.

Table 3: $\quad$ Identification of endophytic bacterial isolates

\begin{tabular}{|c|c|c|c|c|c|c|c|}
\hline \multirow{2}{*}{$\begin{array}{l}\text { Bacterial isolate } \\
\text { number }\end{array}$} & \multirow{2}{*}{$\begin{array}{l}\text { Size of } 16 S \text { rRNA } \\
\text { gene (base pairs) }\end{array}$} & \multicolumn{4}{|c|}{ NCBI BLAST hit results } & \multirow{2}{*}{$\begin{array}{l}\text { Assigned bacterial } \\
\text { isolate/strain name }\end{array}$} & \multirow{2}{*}{$\begin{array}{c}\text { Assigned accession } \\
\text { number }\end{array}$} \\
\hline & & $\begin{array}{c}\text { Dominant bacteria } \\
\text { genus }\end{array}$ & $\begin{array}{c}\% \text { Query } \\
\text { cover }\end{array}$ & E-value & \% Identity & & \\
\hline 1 & 629 & Arthrobacter & 100 & 0 & 100 & $\begin{array}{l}\text { Arthrobacter sp. strain } \\
\text { MHSD1 }\end{array}$ & MF613647 \\
\hline 2 & 604 & Pantoea & 100 & 0 & 99 & $\begin{array}{l}\text { Pantoea sp. strain } \\
\text { MHSD2 }\end{array}$ & MF613648 \\
\hline 3 & 600 & Bacillus & 100 & 0 & 100 & $\begin{array}{l}\text { Bacillus infantis strain } \\
\text { MHSD3 }\end{array}$ & MF613649 \\
\hline 4 & 551 & Pantoea & 100 & 0 & 99 & $\begin{array}{l}\text { Pantoea sp. strain } \\
\text { MHSD4 }\end{array}$ & MF613650 \\
\hline 5 & 557 & Pantoea & 100 & 0 & 99 & $\begin{array}{l}\text { Pantoea ananatis strain } \\
\text { MHSD5 }\end{array}$ & MF613651 \\
\hline 6 & 549 & Pantoea & 100 & 0 & 99 & $\begin{array}{l}\text { Pantoea sp. strain } \\
\text { MHSD6 }\end{array}$ & MF613652 \\
\hline
\end{tabular}




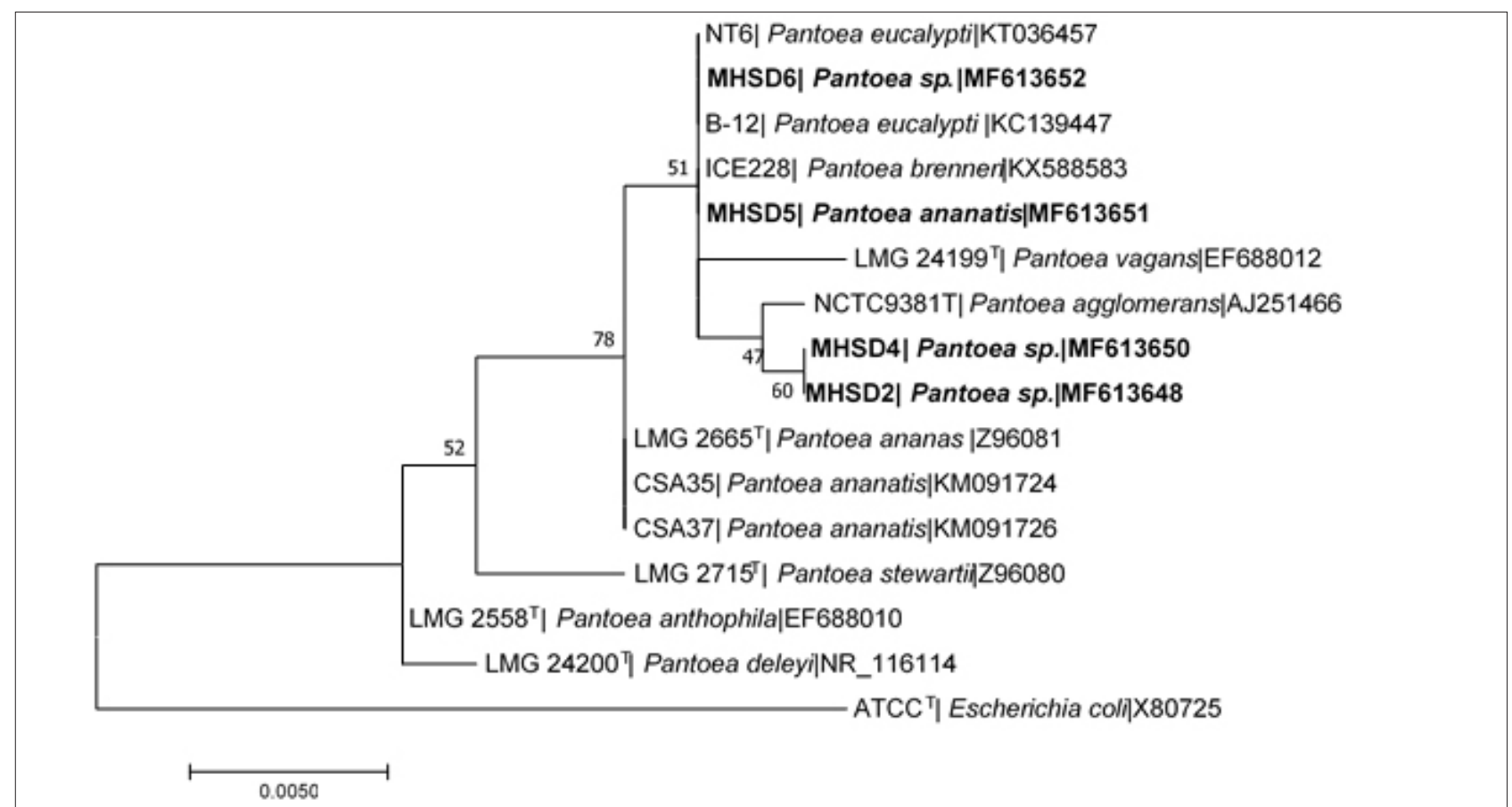

Figure 7: Maximum likelihood tree based on the 16S rRNA gene sequences of Pantoea spp. isolated in this study and their closest phylogenetic neighbours. The numbers on nodes indicate bootstrap values after 1000 replicates expressed in percentages. Escherichia coli strain ATCC X80725 was included as an outgroup. ${ }^{\top}$ indicates type strains.

We isolated bacterial endophytes from only the leaves and we believe the results obtained here will be additional to the minimally reported number of phylloplane bacterial endophytes. ${ }^{4}$ Braithwaite et al. ${ }^{29}$ have reported on the antimicrobial activity of $P$. calomelanos against bacterial pathogens and yeast. Thus, in exploring the antimicrobial activity and other potential applications of bacterial endophytes from this plant, we had to identify and understand its associated bacterial endophytes.

Pantoea spp., Bacillus spp. and Arthrobacter spp. are common soil bacteria. Furthermore, these bacterial species have been previously isolated from maize, rice and medicinal plants as bacterial endophytes. ${ }^{30-33}$ Although they are considered to be plant endophytes, bacteria from the same genera as the reported bacterial endophytes have also been isolated from diseased plants and clinical samples. ${ }^{27,34}$ From these reports and observations, there is a need to understand the evolutionary relationships of these bacterial species, and also the occurrences and differences between bacterial endophytes as plant endophytes and as phytopathogens. Therefore, we recommend that whole genome sequencing and comparisons can provide more comprehensive insights to resolve the evolutionary relationships and identify the bacterial groups to strain level, as well as to identify genetic components that prompt the occurrence of bacterial species as bacterial endophytes.

Soil type ${ }^{35}$, season ${ }^{36,37}$ and host type ${ }^{38,39}$ have been reported to affect the diversity and seasonal fluctuations of bacterial endophytes. These factors could explain the low number of bacterial endophytes isolated from the current study. Furthermore, the Pantoea genus was dominant, with four identified Pantoea species, and we strongly believe that more bacterial endophytes are likely associated with $P$. calomelanos. Further studies are underway to isolate and identify bacterial endophytes from $P$. calomelanos collected in different seasons and from different soil types. Methods which are culture independent can also be employed in identifying bacterial endophytes.

Bacterial endophytes produce the same or similar metabolites as their hosts. Therefore, because $P$. calomelanos has antibacterial and antifungal activities, the ability of bacterial endophytes from this plant to produce metabolites which (1) have therapeutic activity, (2) are similar to those produced by $P$. calomelanos and (3) have other possible potential applications, needs to be studied.

\section{Conclusion}

Bacterial endophytes from $P$. calomelanos are poorly studied. The current study provides information on the isolation and diversity of bacterial endophytes from $P$. calomelanos. This study is a pilot to ongoing research on $P$. calomelanos obtained in South Africa, on its secondary metabolites and bacterial endophytes and potential application of the secondary metabolites and bacterial endophytes. Furthermore, whole genomic studies are underway to understand the evolutionary relationships between bacteria that occur as plant endophytes and plant pathogens. The genomic components that drive the symbiosis between $P$. calomelanos and its bacterial endophytes will also form part of future studies.

\section{Acknowledgements}

We thank the Faculty Research Committee and University Research Committee of the University of Johannesburg for funding this research. We are thankful to Mr Rudzani Manafe and Mr Witness Qaku for their technical support. Mr Siphiwe G. Mahlangu received the NRF Scarce Skills Master's scholarship (grant number SFH160628174791).

\section{Authors' contributions}

M.H.S-D. conceptualised the research; S.G.M. conducted the experiments; both authors analysed the data and contributed to the writing and editing of the manuscript.

\section{References}

1. Guo LD, Hyde KD, Liew ECY. Identification of endophytic fungi from Livistona chinensis based on morphology and rDNA sequences. New Phytol. 2000;147:617-630. https://doi.org/10.1046/j.1469-8137.2000.00716.x

2. Chojniak J, Jalowiecki L, Dorgeloh E, Hegedusova B, Ejhed H, Magner J, et al. Application of the BIOLOG system for characterization of Serratia marcescens ss marcescens isolated from onsite wastewater technology (OSWT) *. Acta Biochim Pol. 2015;62(4):799-805. https://doi.org/10.18388/ abp.2015_1138 
3. Toghueo RMK, Zabalgogeazcoa I, Vazquez de Aldana BR, Boyom FF. Enzymatic activity of endophytic fungi from medicinal plants Terminalia catappa, Terminalia mantaly and Cananga odorata. S Afr J Bot. 2017;109:146-153. https://doi.org/10.1016/j.sajb.2016.12.021

4. Gouda S, Das G, Sen SK, Shin H, Patra JK. Endophytes: A treasure house of bioactive compounds of medicinal importance. Front Microbiol. 2016;7, Art. \#1538, 8 pages. https://doi.org/10.3389/fmicb.2016.01538

5. Strobel GA. Endophytes as sources of bioactive products. Microb Infect. 2003;5(6):535-544. https://doi.org/10.1016/S1286-4579(03)00073-X

6. Ding T, Melcher U. Influences of plant species, season and location of leaf endophytic bacterial communities of non-cultivated plants. PLoS ONE. 2016;11(3), e0150895, 13 pages. https://doi.org/10.1371/journal. pone. 0150895

7. Schuettplez E, Schneider H, Huiet L, Windham MD, Pryer KM. A molecular phylogeny of the fern family Pteridaceae: Assessing overall relationships and the affinities of previously unsampled genera. Mol Phylogenet. Evol. 2007;44(3):1172-1185. https://doi.org/10.1016/j.ympev.2007.04.011

8. Alan RS, Kathleen MP, Eric S, Peter K, Harald S, Paul GW. A classification for extant ferns. Taxon. 2007;55(3):705-731.

9. South African National Biodiversity Institute (SANBI). Pellaea calomelanos [homepage on the Internet]. c2017 [cited 2017 Jul 30]. Available from: http:// pza.sanbi.org/pellaea-calomelanos

10. Muthukumar T, Prabha K. Aubuscular mycorrhizal and septate endophyte fungal associations in lycophytes and ferns of south India. Symbiosis. 2013;59(1):15-33. https://doi.org/10.1007/s13199-012-0185-z

11. Tarnau K, Anielska T, Jurkiewicz A. Mycothallic/mycorrhizal symbiosis of chlorophyllous gametophytes and sporophytes of a fern, Pellaea viridis (Forsk.) Prantl (Pellaeaceae, Pteridales). Mycorrhiza. 2005;15(2):121-128. https://doi.org/10.1007/s00572-004-0306-5

12. Cruikshank R, Duguid JP, Marmoin BP, Swain RH. Medical microbiology. 12th ed. New York: Longman Group Limited; 1975.

13. Prescott LM, Harley JP, Klein DA. Laboratory exercises in microbiology. 5th ed. New York: McGraw-Hill; 2002.

14. MacFaddin J. Biochemical tests for identification of medical bacteria. 3rd ed. Philadelphia, PA: Lippincott Williams \& Wilkins; 2000.

15. MicroStation ${ }^{\mathrm{TM}}$ System/MicroLog ${ }^{\mathrm{TM}}$ user guide. A powerful automated system for the rapid identification of bacteria, yeasts and filamentous fungi. Hayward, CA; Biolog; 2010.

16. Yeates $C$, Gillings MR, Davison AD, Altavilla N, Veal DA. PCR amplification of crude microbial DNA extracted from soil. Lett Appl Microbiol.1997;25:303-307. https://doi.org/10.1046/j.1472-765X.1997.00232.x

17. Tamura K, Nei M. Estimation of the number of nucleotide substitutions in the control region of mitochondrial DNA in humans and chimpanzees. Mol Biol Evol. 1993;10:512-526.

18. Kumar S, Stecher G, Tamura K. MEGA 7: Molecular Evolutionary Genetics Analysis version 7.0 for bigger datasets. Mol Biol Evol. 2016;33(7):18701874. https://doi.org/10.1093/molbev/msw054

19. Jasim B, Joseph AA, John CJ, Mathew J. Isolation and characterization of plant growth promoting endophytic bacteria from the rhizome of Zingiber officinale. 3 Biotech. 2014;4(2):197-204. https://doi.org/10.1007/s13205013-0143-3

20. Long HH, Schmidt DD, Baldwin IT. Native bacterial endophytes promote host growth in a species-specific manner; phytohormone manipulations do not result in common growth responses. PLoS One. 2008;3(7), e2702, 10 pages. https://doi.org/10.1371/journal.pone.0002702

21. Ashkan MF, Bleakly B. Isolation, characterization and identification of putative bacterial endophytes from some plants in Hot Springs, South Dakota. Int J Curr Microbiol App Sci. 2017;6(6):756-767. https://doi.org/10.20546/ ijcmas.2017.606.089

22. Fouda AH, Hassan SE, Eid AM, Ewais EE. Biotechnological applications of fungal endophytes associated with medicinal plant Asclepias sinaica (Bioss.). Ann Agric Sci. 2015;50(1):95-104. https://doi.org/10.1016/j. aoas.2015.04.001
23. Azevedo JL, Quecine MC. Diversity and benefits of microorganisms from the tropics. Zug, Switzerland: Springer International Publishing AG; 2017. https:// doi.org/10.1007/978-3-319-55804-2

24. Wu W, Yang F, Bai L. Influence of substrate on electricity generation of Shewanella loihica PV-4 in microbial fuel cells. Microb Cel Fact. 2014;13, Art. \#69, 6 pages. https://doi.org/10.1186/1475-2859-13-69

25. Pyar $\mathrm{H}$, Peh K. Characterization and identification of Lactobacillus acidophilus using Biolog rapid identification system. Int J Pharm Sci. 2014;6(1):189-193.

26. Stoyanova M, Vancheva T, Moncheva P, Bogatzevska N. Differentiation of Xanthomonas spp. causing bacterial spot in Bulgaria based on Biolog system. Int J Microbiol. 2014;2014, Art. \#495476, 7 pages. https://doi. org/10.1155/2014/495476

27. Brady CL, Venter SN, Cleenwerck I, Engelbeen K, Vancanneyt M, Swings J, et al. Pantoea vagans sp. Nov., Pantoea eucalypti sp. Nov., Pantoea deleyi sp. Nov and Pantoea antophila sp. Nov. Int J Syst Evol Microbiol. 2009;59:23392345. https://doi.org/10.1099/ijs.0.009241-0

28. Grevers D, Cohan FM, Lawrence JG, Spratt BG, Coenye T, Feil EJ, et al. Reevaluating prokaryotic species. Nat Rev Microbiol. 2005;3:733-739. https:// doi.org/10.1038/nrmicro1236

29. Braithwaite M, Van Vuuren SF, Viljoen AM. Validation of smoke inhalation therapy to treat microbial infections. J Ethnopharmacol. 2008;119(3):501506. https://doi.org/10.1016/j.jep.2008.07.050

30. Xiong $X Q$, Liao HD, Liu XM, Zhang LY, Shi XW, Yang XL, et al. Isolation of a rice endophytic bacterium, Pantoea $\mathrm{Sp}$. Sd-1 with ligninolytic activity and characterization of its rice straw degradation ability. Lett Appl Microbiol. 2013;58:123-129. https://doi.org/10.1111/lam.12163

31. Sheibani-Tezerji R, Naveed M, Jehl MA, Sessitsch A, Rattei T, Mitter B. The genomes of closely related Pantoea ananatis maize seed endophytes having different effects on the host plant differ in secretion system genes and mobile genetic elements. Front Microbiol. 2015;6, Art. \#440, 16 pages. https://doi. org/10.3389/fmicb.2015.00440

32. Egamberdieva D, Wirth S, Behrendt U, Ahmad P, Berg G. Antimicrobial activity of medicinal plants correlates with the proportion of antagonistic endophytes. Front Microbiol. 2017;8, Art. \#199, 11 pages. https://doi.org/10.3389/ fmicb.2017.00199

33. Loh CY, Tan Y, Rohani R, Weber JF, Bhore SJ. Diversity of endophytic bacteria in Malaysian plants as revealed by $16 \mathrm{~S}$ rRNA encoding gene sequence based method of bacterial identification. J Young Pharm. 2013;5:95-97. https://doi. org/10.1016/j.jyp.2013.07.001

34. Brady C, Cleenwerck I, Venter S, Vancanneyt M, Swings J, Coutinho T. Phylogeny and identification of Pantoea species associated with plants, humans and the natural environment based on multilocus sequence analysis (MLSA). Syt Appl Microbiol. 2008;31:447-460. https://doi.org/10.1016/j. syapm.2008.09.004

35. Hardoim PR, Hardoim CC, Van Overbeek LS, Van Elsas JD. Dynamics of seedborne rice endophytes on early plant growth stages. PLoS One. 2012;7(2), e30438, 13 pages. https://doi.org/10.1371/journal.pone.0030438

36. Forchetti G, Masciarelli 0, Izaguirre MJ, Alemano S, Alvarez D, Abdala G. Endophytic bacteria improve seedling growth of sunflower under water stress, produce salicylic acid, and inhibit growth of pathogenic fungi. Curr Microbiol. 2010;61:485-493. https://doi.org/10.1007/s00284-010-9642-1

37. Gao XX, Zhou H, Xu DY, Yu CH, Chen YQ, Qu LH. High diversity of endophytic fungi from the pharmaceutical plant, Heterosmilax japonica Kunth revealed by cultivation-independent approach. FEMS Microbiol Lett. 2005;249:255-266. https://doi.org/10.1016/j.femsle.2005.06.017

38. Ding T, Palmer MW, Melcher U. Community terminal restriction fragment length polymorphisms reveal insights into the diversity and dynamics of leaf endophytic bacteria. BMC Microbiol. 2013;13, Art. \#1, 11 pages. https://doi. org/10.1186/1471-2180-13-1

39. Hunter PJ, Hand P, Pink D, Whipps JM, Bending GD. Both leaf properties and microbe-microbe interactions influence within-species variation in bacterial population diversity and structure in the lettuce (Lactuca species) phyllosphere. Appl Env Microbiol. 2010;76(24):8117-8125. https://doi. org/10.1128/AEM.01321-10 